\title{
Subcutaneous Tissue Response of Isogenic Mice to Calcium Hydroxide-Based Pastes with Chlorhexidine
}

\author{
Raquel Assed Bezerra da SILVA ${ }^{1}$ \\ Sada ASSED ${ }^{1}$ \\ Paulo NELSON-FILHO ${ }^{1}$ \\ Léa Assed Bezerra da SILVA ${ }^{1}$ \\ Alberto CONSOLARO ${ }^{2}$ \\ ${ }^{1}$ Department of Pediatric Clinic, Preventive and Community Dentistry, Ribeirão Preto Dental School, \\ University of São Paulo, Ribeirão Preto, SP, Brazil \\ ${ }^{2}$ Department of Oral Pathology, Bauru Dental School, University of São Paulo, Bauru, SP, Brazil
}

\begin{abstract}
This study was evaluated the response of subcutaneous connective tissue of isogenic mice to calcium hydroxide-based pastes with chlorhexidine digluconate (CHX). Seventy isogenic male BALB/c mice aged 6-8 weeks and weighing 15-20 g were randomly assigned to 8 groups. The animals received polyethylene tube implants as follows: Groups I, II, and III $(n=10)-$ Calen ${ }^{\circledR}$ paste mixed with $0.4 \%$ CHX (experimental paste; Calen/CHX) for 7, 21, and 63 days, respectively; Groups IV, V, and VI (n=10) - UltraCal ${ }^{\mathrm{TM}}$ paste mixed with 2\% CHX (experimental paste supplied by Ultradent Products Inc.; Ultracal/CHX) for 7, 21, and 63 days, respectively; and Groups VII and VIII ( $\mathrm{n}=5)$ : empty tube for 7 and 21 days, respectively. At the end of the experimental periods, the implants were removed together with the surrounding tissues (skin and subcutaneous connective tissue). The biopsied tissues were subjected to routine processing for histological analysis. Using a descriptive analysis and a four-point (0-3) scoring system, the following criteria were considered for qualitative and quantitative analysis of the tissue around the implanted materials: collagen fiber formation, tissue thickness and inflammatory infiltrate. A quantitative analysis was performed by measuring the thickness $(\mu \mathrm{m})$, area $\left(\mu \mathrm{m}^{2}\right)$ and perimeter $(\mu \mathrm{m})$ of the reactionary granulomatous tissue formed at the tube ends. Data were analyzed statistically by the Kruskal-Wallis test and Dunn's posttest $(\alpha=0.05)$. Calen/CHX showed biocompatibility with the subcutaneous and reactionary tissues, with areas of discrete fibrosis and normal conjunctive fibrous tissue, though without statistically significant difference $(p>0.05)$ from the control groups. In Groups I to III, there was a predominance of score 1, while in Groups IV to VI scores 2 and 3 predominated for all analyzed parameters. UltraCal/ $\mathrm{CHX}$, on the other hand, induced the formation of an inflammatory infiltrate and abundant exudate, suggesting a persistent residual aggression from the material, even 63 days after implant placement. In conclusion, the Calen paste mixed with $0.4 \%$ CHX allowed an adequate tissue response, whereas the UltraCal paste mixed with $2 \%$ CHX showed unsatisfactory results.
\end{abstract}

Key Words: calcium hydroxide, chlorhexidine, subcutaneous tissue, tissue response.

\section{INTRODUCTION}

Different substances have been associated with calcium hydroxide in an effort to improve physicochemical properties such as radiopacity, viscosity, leakage, antimicrobial action and ionic dissociation rate for long-term use in the endodontic treatment of teeth with pulp necrosis and apical periodontitis (1). Among these substances, chlorhexidine digluconate ( $\mathrm{CHX}$ ) has been used to increase the antibacterial activity of calcium hydroxide against resistant microorganisms $(1,2)$. While $\mathrm{CHX}$ cannot inactive the bacterial LPS $(3,4)$ or dissolve organic tissues when used alone (5), it has a broad-spectrum antibacterial action against Gram-positive and Gram-negative bacteria, aerobic 
and anaerobic microorganisms, yeasts and fungi (6). In addition, CHX has been proven effective against the most common microorganisms in endodontic infections even when used at low concentrations (7).

Although the association of calcium hydroxide and CHX can be advantageous for the endodontic treatment due to the increased synergic antimicrobial effect compared to the treatment using calcium hydroxide alone $(8,9)$, the biocompatibility of this association has not been widely investigated (10). The purpose of this study was to evaluate the response of the subcutaneous connective tissue of isogenic mice to the implantation of polyethylene tubes filled with calcium hydroxide pastes mixed with $\mathrm{CHX}$ at different concentrations.

\section{MATERIAL AND METHODS}

The research protocol was reviewed and approved by the Research Ethics Committee of the University of São Paulo, Brazil, in compliance with the ethical guidelines for animal experimentation.

Seventy isogenic male BALB/c mice aged 6-8 weeks and weighing $15-20 \mathrm{~g}$ were obtained from the Laboratory Animal Care Facility of the Medical School of Ribeirão Preto, Brazil, and were divided into 8 groups. Each animal received one polyethylene tube implant $(10 \mathrm{~mm}$ long $\mathrm{x} 1$ $\mathrm{mm}$ diameter) on the dorsal region as follows: Groups I, II and III ( $\mathrm{n}=10)$ : Calen ${ }^{\circledR}$ paste (S.S.White Artigos Dentários Ltda., Rio de Janeiro, RJ, Brazil; composition: 2.5 $\mathrm{g}$ calcium hydroxide, $0.5 \mathrm{~g}$ zinc oxide, $0.05 \mathrm{~g}$ colophony and $1.75 \mathrm{~mL}$ polyethylene glycol 400 ) mixed with $0.4 \%$ CHX (Farmoderm, São Paulo, SP, Brazil) (experimental paste; Calen/CHX) for 7, 21, and 63 days, respectively; Groups IV, V, and VI ( $\mathrm{n}=10)$ : UltraCal ${ }^{\mathrm{TM}}$ paste (Ultradent Products Inc., South Jordan, UT, USA; composition: 35\% calcium hydroxide, and barium sulfate) mixed with $2 \%$ CHX (Farmoderm), supplied by Ultradent Products Inc. for 7, 21, and 63 days, respectively; and Groups VII and VIII ( $n=5)$ - empty tube for 7 and 21 days, respectively. All polyethylene tubes had their ends closed by using sterile heated clinical tweezers, and were then sterilized with ethylene oxide, and filled with the materials under aseptic conditions immediately prior to use and implantation.

Before tube implantation, the animals were anaesthetized with an intraperitoneal injection of $10 \%$ chloral hydrate $(1 \mathrm{~mL} / 100 \mathrm{~g}$ body weight $)$, and had the dorsal region shaved and cleaned with a $1 \%$ CHX solution (Farmoderm). A 1-cm-wide incision was made on the dorsal region fol- lowed by tissue divulsion with Kelly forceps, and the tube was inserted into the connective tissue and the skin borders were closed with 4-0 silk sutures (Vicryl; Johnson \& Johnson: Ethicon Inc., New Brunswick, NJ, USA). The surgery was performed under aseptic conditions to minimize the trauma to the implant area. The animals were kept with free access to standard chow and water during the experimental periods and were periodically observed for local, systemic and behavioral abnormalities.

At the end of each experimental period, the animals were anaesthetized again for implant removal together with the surrounding tissues (skin and subcutaneous connective tissue), and were sacrificed by anesthetic overdose. The biopsied tissues were fixed in $10 \%$ buffered formalin solution for $48 \mathrm{~h}$ and then subjected to routine processing for histological analysis. Serial 4-5- $\mu$ m-thick sections were made parallel to the tube long axis and stained with hematoxylin and eosin. The specimens were examined by a trained pathologist with a light binocular microscope (Olympus, Tokyo, Japan) at 4, 10, 40, and 100× magnifications and subjected to descriptive qualitative analysis. Using a 4-point (0-3) scoring system, the following criteria were considered for a quantitative analysis of the tissue arround the implant: Collagen fiber formation: number and density of collagen fibers permeating peripheral cells located within the reactionary tissue arround the implant. Severity classification: 0 (absence), 1 (mild), 2 (moderate), 3 (intense); Tissue thickness: number of fibroblasts and macrophages associated with and juxtaposed to the material surface in relation to peripheral connective tissue. Severity classification: 0 (normal), 1 (slightly increased), 2 (moderately increased), 3 (intensely increased); Inflammatory infiltrate: concentration of polymorphonuclear neutrophils permeating the reactionary tissue arround the implant. Severity classification: 0 (absence), 1 (mild), 2 (moderate), 3 (intense).

A quantitative analysis was performed in all experimental groups by measuring the thickness $(\mu \mathrm{m})$, area $\left(\mu \mathrm{m}^{2}\right)$ and perimeter $(\mu \mathrm{m})$ of the reactionary granulomatous tissue formed at the tube ends. The microscopic images were captured and transferred to image-analysis software (J 1.28 u, National Institute of Health, Staten Island, NY USA). The study was designed according to the guidelines of the ISO 10993-6 standard (1994).

Data were analyzed statistically by the nonparametric Kruskal-Wallis test and Dunn's post-test at 5\% significance level using GraphPad statistical software (GraphPad Software Inc., San Diego, CA, USA). 


\section{RESULTS}

\section{Qualitative Microscopic Analysis}

Group I(Calen/CHX- 7 days) (Figs. 1 A and B): The tissue-material interface presented well-defined fibroblasts parallel to the surface, and the reactionary tissue was well organized. Macrophage phagocytosis of thin basophilic granular particles within the material was observed as well as a residual number of neutrophils.

Group II (Calen/CHX - 21 days) (Figs. $1 \mathrm{C}$ and D): Discrete number of fibroblasts was seen at the tissuematerial interface with sporadic neutrophils. The reactionary tissue resembled a normal fibrous connective tissue. In some specimens, macrophages were found at the interface and in direct contact with the material, and inflammatory multinucleated foreign body giant cells. Only few macrophages had engulfed thin basophilic material granulations in their cytoplasm.

Group III (Calen/CHX - 63 days) (Figs. $1 \mathrm{E}$ and F): The surrounding and reactionary tissues showed little collagen fiber formation and had the appearance of a normal fibrous connective tissue with a characteristic capsular organization. A large number of macrophages and inflammatory multinucleated foreign body giant cells were observed at the tissue-material interface. The reactionary tissue thickness was reduced and no neutrophil infiltration was seen.

Group IV (UltraCal/CHX- 7 days) (Figs. 2Aand B): The material showed multiple small irregular-shaped basophilic particles at the tissue-material interface surrounded by reactionary tissue. Morphologically, the material surface was dissolved, probably due to the enzymes released from exudate and/or inflammatory cells. Collagen fiber formation ranged from mild to moderate, and the reactionary was thicker due to the presence of exudate and demarked by negative spaces between macrophages and fibroblasts. The macrophages were predominantly ovoid and swollen, with their cytoplasm rich in material particles. Inflammatory multinucleated foreign body giant cells were sporadically observed at the tissue-material interface. Five specimens showed extravasation of the material from the tube end.

Group V (UltraCal/CHX - 21 days) (Figs. $2 \mathrm{C}$ and D): The reactionary tissue surrounding the material was thicker and had a large number of macrophages and several fibroblasts. The vessels were dilated and some specimens had a large number of neutrophils, most of which presenting prolonged residual activity. The collagen fibers found in some areas were not well defined, forming hyaline areas in the extra-cellular matrix. Most macrophages had engulfed material particles in their cytoplasm. Material extravasation occurred in 3 out of 10 specimens of this group.

Group VI (UltraCal/CHX - 63 days) (Figs. 2 E and F): Little collagen fiber formation was observed at the tissuematerial interface. There was neutrophil inflammatory infiltrate associated with a large number of macrophages and congested vessels, and abundant exudate. These characteristics are suggestive of a persistent residual aggression from the material, even 63 days after its implantation. Material extravasation was observed in 4 specimens, thus inducing to a foreign body-type granulomatous reaction.

Group VII (Empty tube - 7 days): Tissue response close to the ends of the empty tube was determined by a large number of fibroblasts permeated by macrophages and some neutrophils. No inflammatory multinucleated foreign body giant cells were observed in this region. On the other hand, tissue response close to the lateral walls of the polyethylene tube was far less intense, with few giant cells and macrophages on the surface. Regarding tissue morphology, the reactionary tissue showed fibrous formation and structural organization similar to those of a fibrous connective tissue.

Group VIII (Empty tube - 21 days): The reactionary tissue at the tube ends was thinner than that observed on day 7 and also presented less collagen fiber formation. Macrophages were associated with some neutrophils and inflammatory multinucleated foreign body giant cells. Compared to the lateral walls of the tube, tissue response close to the tube ends was characterized by a larger number of cells and greater thickness.

\section{Quantitative Microscopic Analysis}

Calen/CHX Groups: Regarding collagen fiber formation, described as the number and density of collagen fibers permeating peripheral cells, only scores 1 (mild fiber formation in the tissue surrounding the material - 75\%) and 2 (moderate fiber formation - 25\%) were attributed on day 7. On days 21 and 63, all specimens received score 1. Regarding tissue thickness, scores 1 (slightly increased), 2 (moderately increased), and 3 (intensely increased) were attributed, with a predominance of score $2(50 \%)$ on day 7. On days 21 and 63, all specimens received score 1. Regarding the inflammatory infiltrate intensity, represented by the concentration of polymorphonuclear neutrophils, only scores 1 (mild - 60\%) and 3 (intense - 40\%) were attributed on day 7. On day 21 (Fig. 3), the specimens 

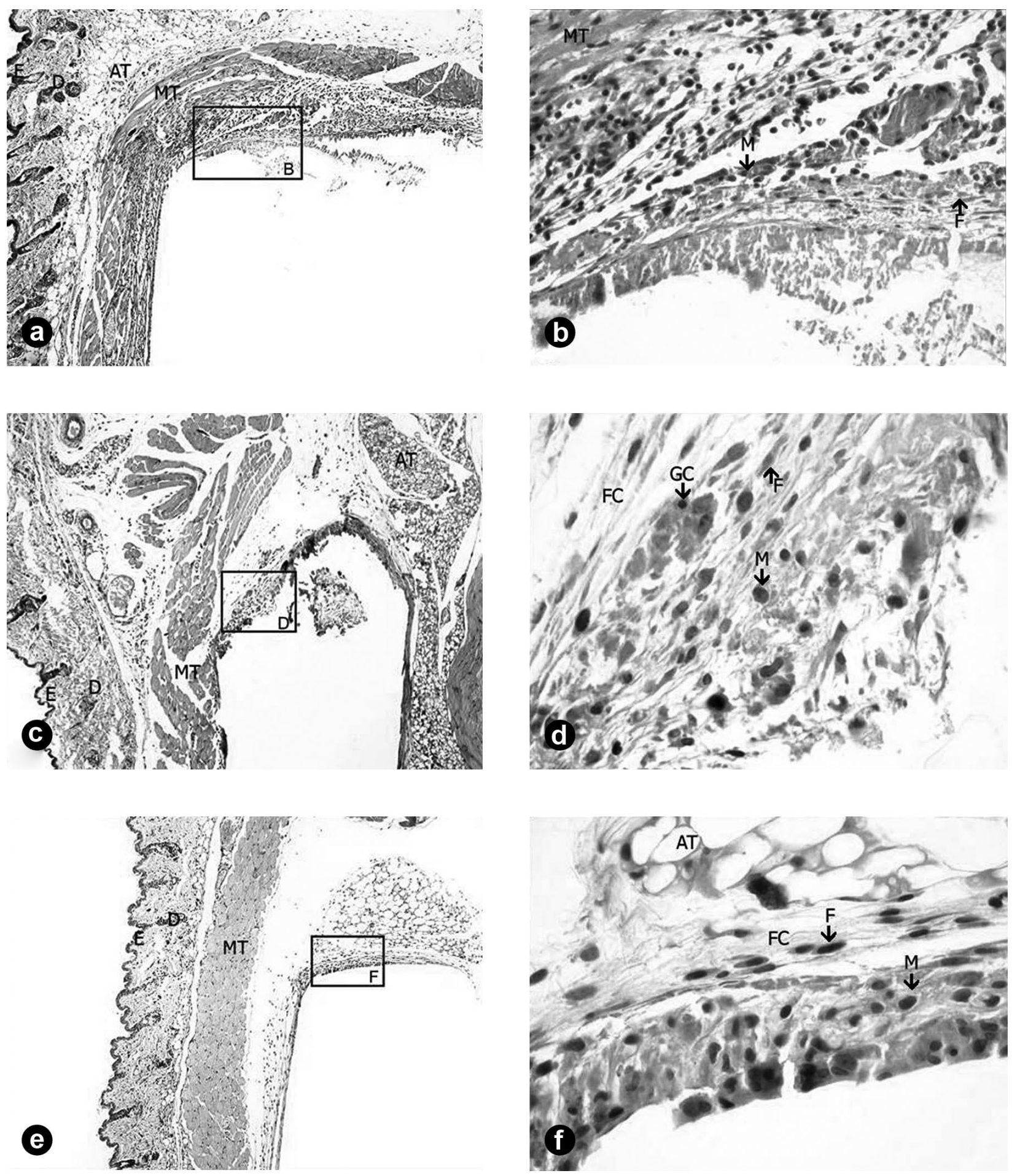

Figure 1. Calen paste plus 0.4 CHX: A and B - On day 7, reactionary tissue was thin with mild exudate, being also rich in macrophages (M) and young fibroblast (F) presenting discrete fibrosing activity (HE; $\mathrm{A}=\times 4$ and $\mathrm{B}=\times 40$ ). $\mathrm{C}$ and $\mathrm{D}$ - On day 21 , reactionary tissue had discrete thickness presenting discrete fibrosing activity. Macrophages (M) were predominantly observed and intermingled with fibroblasts $(\mathrm{F})$, and inflammatory multinucleated giant cells $(\mathrm{GC})$ were observed $(\mathrm{HE} ; \mathrm{C}=\times 4$ and $\mathrm{D}=\times 40)$. $\mathrm{E}$ and $\mathrm{F}-\mathrm{On}$ day 63 , no reactionary tissue had collagen fibers distributed as those at the interface between lateral wall and normal connective tissue. There was small thickness but no negative spaces. ( $\mathrm{HE} ; \mathrm{C}=\times 4$ and $\mathrm{D}=\times 40$ ). $\mathrm{E}=$ epidermis; $\mathrm{D}=$ dermis; $\mathrm{FC}=$ fibrous capsule; $\mathrm{AT}=$ adipose tissue; MT = muscular tissue. 

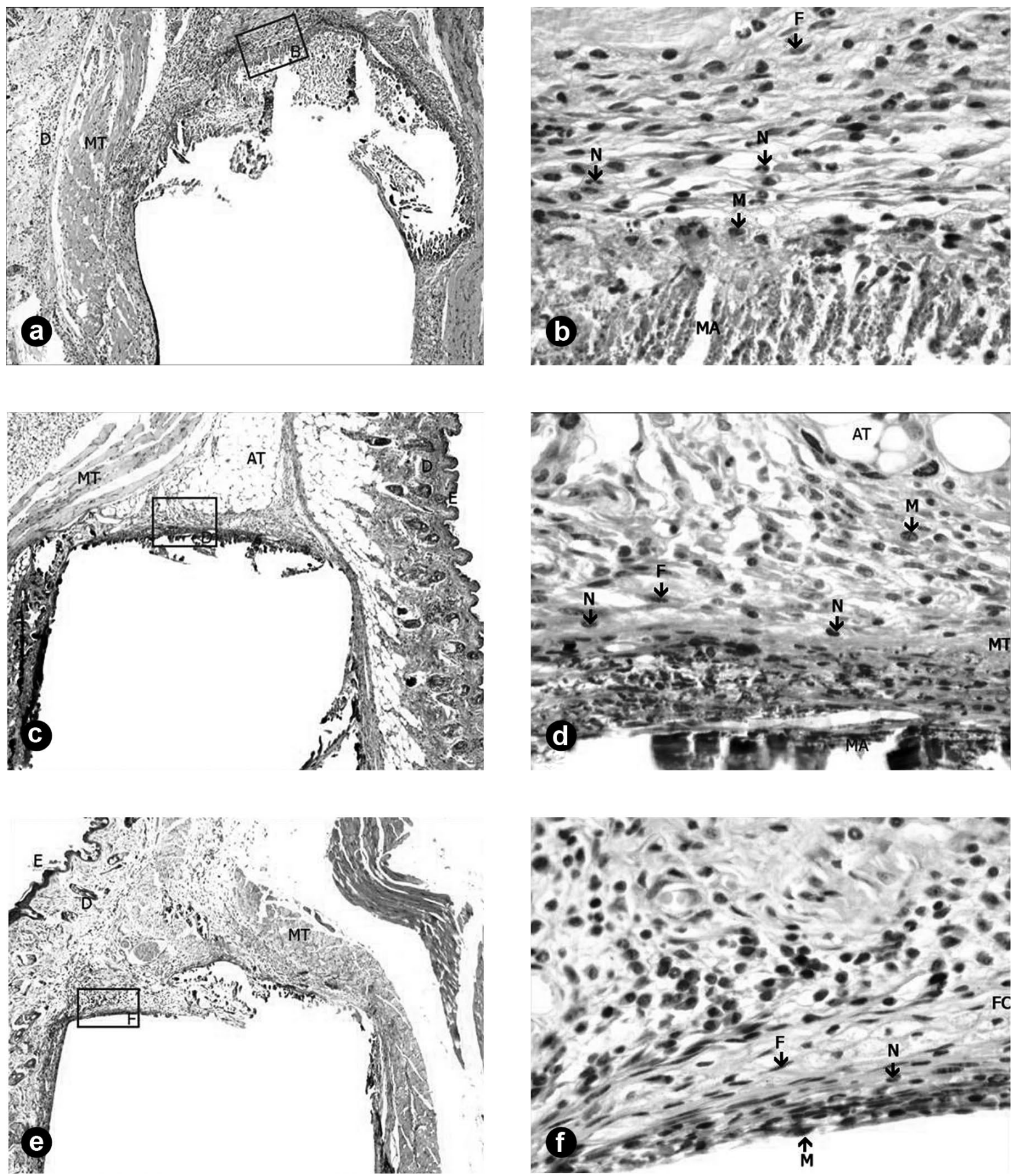

Figure 2. Ultracal plus 2\% CHX: A and B - On day 7, reactionary tissue was thick and had severe exudate, and mild fibrosing activity and macrophages (M) were swollen and had microvacuoles, suggesting material phagocytosis and material accumulation in the cytoplasm. A few neutrophils $(\mathrm{N})$ were observed among macrophages and fibroblasts (HE; A $=\times 4$ and $B=\times 40$ ). $\mathrm{C}$ and $\mathrm{D}-\mathrm{On}$ day 21 , reactionary tissue were still thick, with neutrophils $(\mathrm{N})$ diffusely distributed. Fibrosing activity was discrete and the macrophages (M) were predominantly observed and intermingled with fibroblasts $(\mathrm{F})(\mathrm{HE} ; \mathrm{C}=\times 4$ and $\mathrm{D}=\times 40)$. E and $\mathrm{F}$ - On day 63 , there were collagen fibers, exudate, macrophage infiltrate permeated by some neutrophils $(\mathrm{N})$, and congested vessels. $(\mathrm{HE} ; \mathrm{C}=\times 4$ and $\mathrm{D}=\times 40)$. $\mathrm{E}=$ epidermis $; \mathrm{D}=$ dermis $; \mathrm{FC}=$ fibrous capsule; $\mathrm{AT}=$ adipose tissue; $\mathrm{MT}=$ muscular tissue; $\mathrm{MA}=$ material. 
received scores 0 (absence of inflammatory infiltrate on the tissue surrounding the material - 55\%), $1(40 \%)$ and 2 (5\%). At the last period evaluated (63 days), all specimens received score 0 .

UltraCal/CHX Groups: Regarding collagen fiber formation, only scores $1(65 \%)$ and $2(35 \%)$ were attributed on day 7. On days 21 and 63, all specimens received score 2. For tissue thickness, scores 2 and 3 were attributed, with a predominance of score $3(80 \%)$ on day 7 and score 2 $(60 \%)$ on day 21 . On day 63 , the specimens received scores $1(15 \%), 2(55 \%)$ and $3(30 \%)$. Regarding the inflammatory infiltrate intensity, the specimens received scores $1(30 \%)$, $2(50 \%)$ and $3(20 \%)$ on day 7 . On days 21 and 63 , scores 1 and 2 were attributed, with a predominance of score 1 (60 and $65 \%$, respectively).

\section{Statistical Analysis}

Score distribution for collagen fiber formation, tissue thickness and inflammatory infiltrate is shown in Figures $3 \mathrm{~A}, 3 \mathrm{~B}$ and $3 \mathrm{C}$.

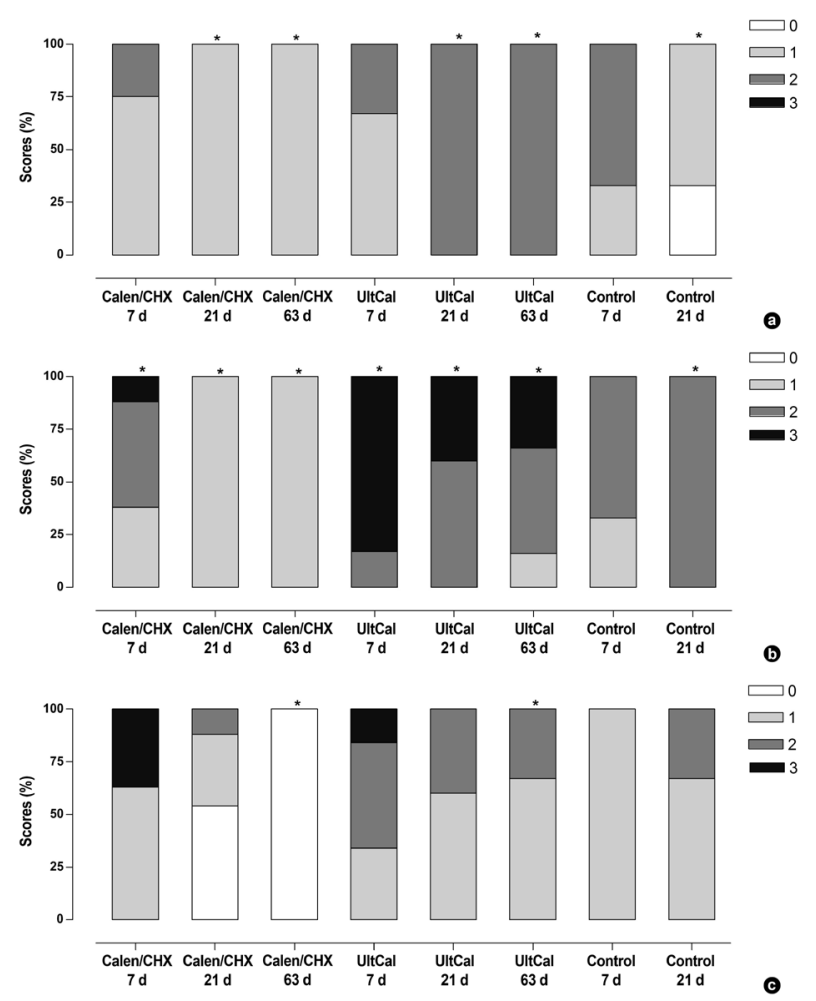

Figure 3. Score distribution in the groups regarding collagen fiber formation (A), tissue thickness (B) and inflammatory infiltrate (C). Statistically significant differences are represented by asterisk $(*)$.
Regarding fiber formation (Fig. 3A), there was no statistically significant difference between the groups on day 7 ( $p>0.05$ ). On day 21, Group V (UltraCal - 21 days) differed significantly $(\mathrm{p}<0.05)$ from Group II (Calen/ CHX - 21 days) and Group VIII (empty tube - 21 days). Regarding tissue thickness (Fig. 3B), there were statistically significant differences $(\mathrm{p}<0.05)$ on day 7 [Groups I (Calen/CHX - 7 days) and IV (UltraCal - 7 days)], on day 21 (Groups II and V), and on day 63 Groups III [(Calen/ CHX - 63 days) and VI (UltraCal - 63 days)].

No significant difference $(p>0.05)$ was found among the groups with regard to inflammatory infiltrate
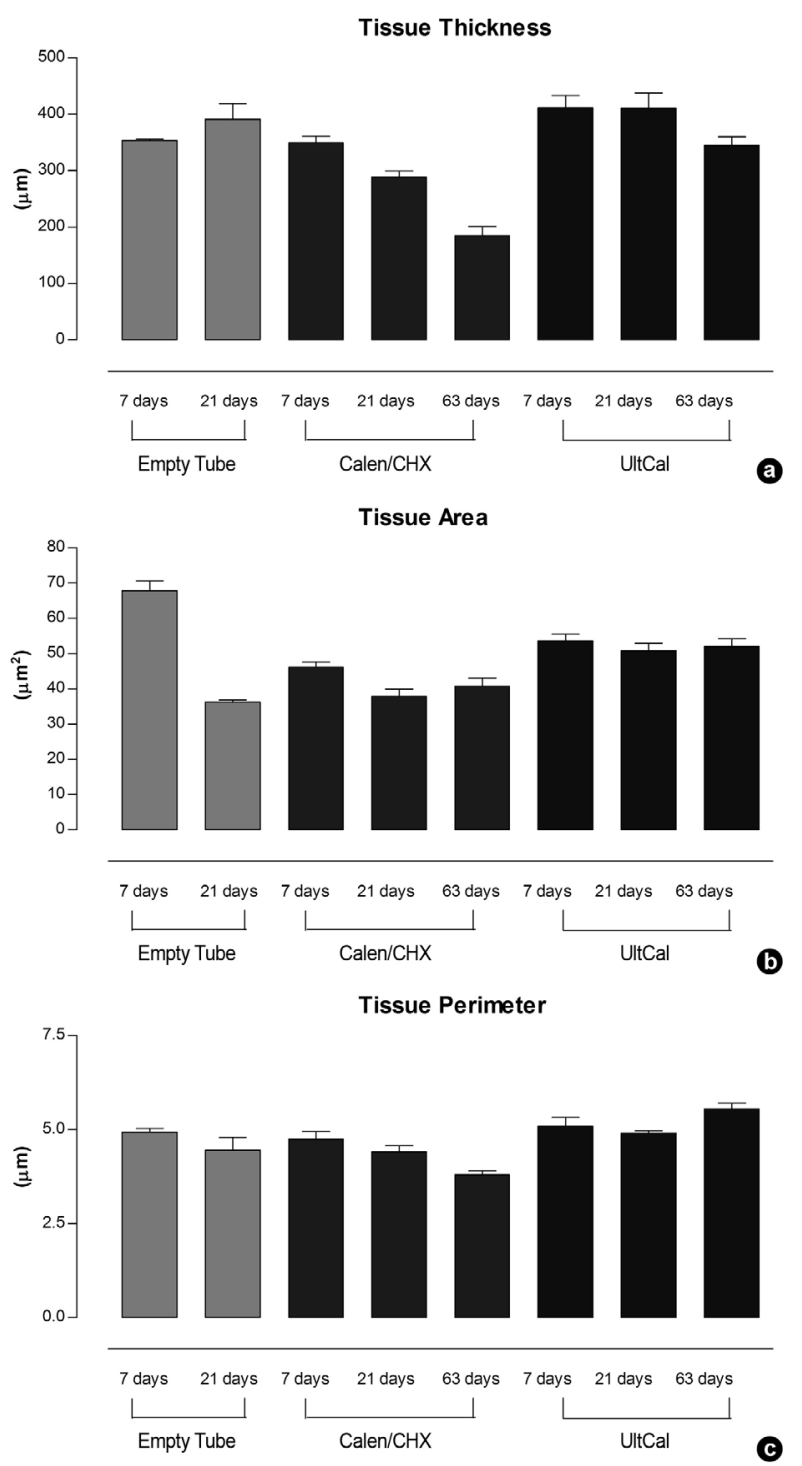

Figure 4. Maximum thickness ( $\mu \mathrm{m})$, area $\left(\mu \mathrm{m}^{2}\right)$ and perimeter $(\mu \mathrm{m})$ of the reactionary granulomatous tissue formed at the tube ends for all groups. 
on days 7 and 21 (Fig. 3C). Significant difference $(\mathrm{p}<0.05)$ was found between Groups III and VI on day 63 .

Figures $4 \mathrm{~A}, 4 \mathrm{~B}$ and $4 \mathrm{C}$ show the measurements for maximum thickness $(\mu \mathrm{m})$, area $\left(\mu \mathrm{m}^{2}\right)$ and perimeter $(\mu \mathrm{m})$ of the reactionary granulomatous tissue formed at the tube ends for all groups. No statistically significant difference ( $p>0.05$ ) was found between the tested materials within the same experimental period.

\section{DISCUSSION}

The biocompatibility of endodontic materials have been evaluated by different methods (11-13), among which the most frequent are in vitro cytotoxicity assays on cell or tissue cultures and biocompatibility tests by implantation of materials in the bone or subcutaneous connective tissue of experimental animals. Although cell culture methods give some valuable information about the response of specific cells to a test material, they do not provide the full picture of how a tissue reacts to the material under in vivo conditions (14). In vivo implantation experiments provide more complete and clinically relevant information on the longterm tissue response (12). Most biocompatibility studies evaluate root canal sealers commonly used in endodontics. Onay et al. (11) have evaluated the in vivo biocompatibility of Epiphany-Resilon resin-based root canal filling system compared to gutta-percha, after implantation in rat connective tissue, and found that all materials had an acceptable biocompatibility. Gomes-Filho et al. (13) have evaluated the rat subcutaneous tissue response to implanted polyethylene tubes filled with a Portland cement modified sealer compared to a calcium hydroxide-based sealer and MTA, and observed that Portland cement was biocompatible and stimulated mineralization.

Although calcium hydroxide is a biocompatible material (15), the different substances that are added to improve its clinical and antimicrobial properties can alter significantly tissue response to this material.

Calen paste is a calcium hydroxide-based material for use as a root canal dressing, which has a recognizably good tissue tolerance (16), though its high alkalinity causes an initial aggressiveness and produces an area of surface necrosis when in contact with living tissues. It occurs because the vehicle (glycol polyethylene 400) used in this paste releases $\mathrm{H}^{+}$, which binds to hydroxyl group $\left(\mathrm{OH}^{+}\right)$, thus buffering the reaction.

The irritating action of CHX in contact with the connective tissue when used alone has also been reported
(17). Therefore, in view of the lack of biocompatibility studies investigating the combination of calcium hydroxide and CHX, this study evaluated the response of subcutaneous connective tissue to 2 commercial calcium hydroxidebased pastes mixed with $\mathrm{CHX}$ at different concentrations. The choice for adding $0.4 \% \mathrm{CHX}$ to the Calen paste was based on the results of a pilot study at our research lab and on the findings of previous studies that evaluated the biocompatibility of CHX at low concentration (17-19). The experimental Ultracal/CHX paste supplied by Ultradent Inc. was also evaluated in order to investigate the possible interference of CHX concentration on the biocompatibility of the calcium hydroxide paste (possible dose-dependent response).

In the present study, the Calen paste mixed with $0.4 \%$ CHX showed microscopic results similar to those of the control groups on days 7 and 21 regarding fiber formation, tissue thickness and inflammatory infiltrate, returning to normality on day 63 . The results obtained using $0.4 \%$ CHX associated with Calen paste were similar to those found in other study using only Calen paste in contact with living tissues (15). The satisfactory results found in the present study were similar to other studies that evaluated $0.4 \% \mathrm{CHX}$ associated with Calen paste in cell cultures. Da Silva et al. (18) has recently shown that no significant changes were observed in terms of cell shape, cell viability, alkaline phosphatase activity, and the total amount of bone-like nodule formation after the cell stimulation with this association. The authors concluded the $0.4 \% \mathrm{CHX}$ associated with the Calen paste does not affect the progression of osteogenic cell cultures, allowing the formation of mineralized nodules in vitro. Another recent study (19) evaluated the effect of the CHX and calcium hydroxide association on RAW 264.7 macrophage cell line culture. Cell viability (MTT assay), immunostimulating properties (nitric oxide dosage) and antiinflammatory properties (TNF- $\alpha$ and IL-1 $\alpha$ dosage) were assessed and the it was concluded that the as the addition of $0.4 \% \mathrm{CHX}$ to Calen paste did not alter cell viability or the immunostimulating and antiinflammatory properties of the paste.

The results of the present study suggest that the tissue response of CHX in association with calcium hydroxide seems to be dose-dependent as since UltraCal/CHX (calcium hydroxide plus $2 \% \mathrm{CHX}$ ) had worse results on days 7,21 and 63 regarding fiber formation, tissue thickness and inflammatory infiltrate than Calen paste associated with $0.4 \%$ CHX. Our findings are also in accordance with those of Schilder and Amsterdam (20), who stated that the use 
of a given drug not only depends on its biological compatibility, but also on its adequate usage and concentration.

Further research is needed before these pastes can be indicated for clinical use. Based on the obtained results and the employed methodology, it may be concluded that adding $0.4 \% \mathrm{CHX}$ to Calen paste allowed adequate tissue response in Balb/c isogenic mice, whereas Ultracal/CHX $2 \%$ showed unsatisfactory results.

\section{RESUMO}

O objetivo do presente estudo foi avaliar a resposta do tecido conjuntivo subcutâneo de camundongos isogênicos frente a pastas à base de hidróxido de cálcio, associadas ao digluconato de clorexidina (CHX). Setenta camundongos isogênicos BALB/c machos, com 6-8 semanas e pesando $15-20 \mathrm{~g}$ foram aleatoriamente divididos em 8 grupos. Os animais receberam implantes de tubos de polietileno contendo: Grupos I, II e III $(\mathrm{n}=10)$ - pasta $\mathrm{Calen}^{\circledR}$ associada à CHX a $0,4 \%$ (Calen/CHX), por 7, 21 e 63 dias, respectivamente; Grupos IV, V e VI $(n=10)$ - pasta UltraCal ${ }^{\mathrm{TM}}$ associada à CHX a 2\% (pasta experimental fornecida pela Ultradent Products Inc.; Ultracal/ CHX), por 7, 21 e 63 dias, respectivamente; e Grupos VII e VIII $(n=5)$ - tubo de polietileno vazio, por 7 e 21 dias, respectivamente. Decorridos os períodos experimentais, os implantes foram removidos juntamente com os tecidos circundantes (pele e tecido conjuntivo). Os tecidos foram submetidos ao processamento histotécnico de rotina, para análise histopatológica. Empregando um sistema de escores, os seguintes critérios foram considerados para a análise qualitativa e quantitativa: fibrosamento, espessura tecidual e infiltrado inflamatório. Foi efetuada, também, a análise quantitativa da medida da espessura $(\mu \mathrm{m})$, área $\left(\mu \mathrm{m}^{2}\right)$ e perímetro $(\mu \mathrm{m})$ do tecido granulomatoso reacional formado na abertura dos tubos. Os dados obtidos foram submetidos à análise estatística, empregando o teste de Kruskal-Wallis e o pós-teste de Dunn. O nível de significância adotado foi de $5 \%$. Os resultados demonstraram biocompatibilidade da pasta Calen associada à CHX a $0,4 \%$ com o tecido adjacente, com fibrosamento discreto, assim como tecido conjuntivo normal, sem diferença estatística significante com os controles ( $\mathrm{p}>0,05)$. Nos Grupos I, II e III houve predominância do escore 1, enquanto que nos Grupos IV, V e VI houve predominância dos escores 2 e 3 , em todos os parâmetros analisados. Em relação à pasta à base de hidróxido de cálcio associada à $\mathrm{CHX}$ a $\%$ (UltraCal $\left.{ }^{\mathrm{TM}}\right)$ observou-se infiltrado inflamatório e exsudato severo, sugerindo uma agressão residual persistente do material testado, mesmo após 63 dias da sua implantação. Em conclusão, a adição de $\mathrm{CHX}$ a $0,4 \%$ à pasta Calen permitiu adequada resposta tecidual, enquanto o hidróxido de cálcio associado à CHX na concentração de $2 \%$ (UltraCal/CHX) evidenciou resultados insatisfatórios.

\section{REFERENCES}

1. Basrani B, Ghanem A, Tjäderhane L. Physical and chemical properties of chlorhexidine and calcium hydroxide-containing medications. J Endod 2004;30:413-417.

2. Schäfer E, Bössmann K. Antimicrobial efficacy of chlorhexidine and two calcium hydroxide formulations against Enterococcus faecalis. J Endod 2005;31:53-56.
3. Silva LA, Leonardo MR, Assed S, Tanomaru Filho M. Histological study of the effect of some irrigating solutions on bacterial endotoxin in dogs. Braz Dent J 2004;15:109-114.

4. De Oliveira LD, Jorge AO, Carvalho CA, Koga-Ito CY, Valera MC. In vitro effects of endodontic irrigants on endotoxins in root canals. Oral Surg Oral Med Oral Pathol Oral Radiol Endod 2007;104:135-142.

5. Okino LA, Siqueira EL, Santos M, Bombana AC, Figueiredo JA. Dissolution of pulp tissue by aqueous solution of chlorhexidine digluconate and chlorhexidine digluconate gel. Int Endod J 2004;37:38-41.

6. Vianna ME, Gomes BP, Berber VB, Zaia AA, Ferraz CC, de SouzaFilho FJ. In vitro evaluation of the antimicrobial activity of chlorhexidine and sodium hypochlorite. Oral Surg Oral Med Oral Pathol Oral Radiol Endod 2004;97:79-84.

7. Do Amorim CV, Aun CE, Mayer MP. Susceptibility of some oral microorganisms to chlorhexidine and paramonochlorophenol. Braz Oral Res 2004;18:242-246.

8. Podbielski A, Spahr A, Haller B. Additive antimicrobial activity of calcium hydroxide and chlorhexidine on common endodontic bacterial pathogens. J Endod 2003;29:340-345.

9. Zerella JA, Fouad AF, Spångberg LS. Effectiveness of a calcium hydroxide and chlorhexidine digluconate mixture as disinfectant during retreatment of failed endodontic cases. Oral Surg Oral Med Oral Pathol Oral Radiol Endod 2005;100:756-761.

10. De Rossi A, Silva LA, Leonardo MR, Rocha LB, Rossi MA. Effect of rotary or manual instrumentation, with or without a calcium hydroxide $/ 1 \%$ chlorhexidine intracanal dressing, on the healing of experimentally induced chronic periapical lesions Oral Surg Oral Med Oral Pathol Oral Radiol Endod 2005;99:628-636.

11. Onay EO, Ungor M, Ozdemir BH. In vivo evaluation of the biocompatibility of a new resin-based obturation system. Oral Surg Oral Med Oral Pathol Oral Radiol Endod 2007;104:e60-66.

12. Bodrumlu E, Muglali M, Sumer M, Guvenc T. The response of subcutaneous connective tissue to a new endodontic filling material. J Biomed Mater Res B Appl Biomater 2008;84:463-467.

13. Gomes-Filho JE, Watanabe S, Bernabé PF, de Moraes Costa MT. A mineral trioxide aggregate sealer stimulated mineralization. J Endod 2009;35:256-260.

14. Sundqvist G, Figdor D. Endodontic treatment of apical periodontitis. In: Orstavik D, Pitt Ford TR, editors. Essential Endodontology, 5th ed. Oxford: Blackwell Scientific Publications; 2003. pp 242-277.

15. Almushayt A, Narayanan K, Zaki AE, George A. Dentin matrix protein 1 induces cytodifferentiation of dental pulp stem cells into odontoblasts. Gene Ther 2006;13:611-620.

16. Nelson Filho P, Silva LAB, Leonardo MR, Utrilla LS, Figueiredo F. Connective tissue responses to calcium hydroxide based root canal medicaments. Int Endod J 1999;32:303-311.

17. Faria G, Celes MR, De Rossi A, Silva LA, Silva JS, Rossi MA. Evaluation of chlorhexidine toxicity injected in the paw of mice and added to cultured L929 fibroblasts. J Endod 2007;33:715-722.

18. Da Silva RA, Leonardo MR, da Silva LA, de Castro LM, Rosa AL, de Oliveira PT. Effects of the association between a calcium hydroxide paste and $0.4 \%$ chlorhexidine on the development of the osteogenic phenotype in vitro. J Endod 2008;34:1485-1489.

19. Da Silva RA, Leonardo MR, da Silva LA, Faccioli LH, de Medeiros AI. Effect of a calcium hydroxide-based paste associated to chlorhexidine on RAW 264.7 macrophage cell line culture. Oral Surg Oral Med Oral Pathol Oral Radiol Endod 2008;106:e44-51.

20. Schilder H, Amsterdam M. Inflammatory potential of root canal medicaments; a preliminary report including nonspecific drugs. Oral Surg Oral Med Oral Pathol. 1959;12:211-221.

Accepted May 25, 2009 